\title{
BCL6 Positive
}

National Cancer Institute

\section{Source}

National Cancer Institute. BCL6 Positive. NCI Thesaurus. Code C132011.

An indication that B-cell lymphoma 6 expression has been detected in a sample. 